УДК 621.565.94

\title{
Дослідження системи попереднього охолодження бінарним льодом на рибодобувних судах
}

\author{
О. В. Зімін ${ }^{\bowtie}$, М. В. Сливинська \\ Одеська національна академія харчових технологій, вул. Канатна, 112, Одеса, 65039, Україна \\ $\triangle$ e-mail: onaft.zimin@ gmail.com, ORCID ID: https://orcid.org/0000-0001-9053-3262
}

\begin{abstract}
Розробка безперервного холодильного ланцюга завжди була важливим завданням у галузі переробки морепродуктів. Зберігання продукту при заданому температурному рівні на протязі його життєвого ициклу забезпечує кінцеву якість. У рибопромисловій справі холодильний ланцююг починається з моменту появи риби на борту судна. Для забезпечення максимальної якості та мінімізачії втрат продукт необхідно швидко охолодити до температури близької до кріоскопічної. Далі треба підтримувати ией температурний режим, бажано уникаючи коливань, до наступного етапу переробки продукту. Для вирішення цієї проблеми пропонується система попереднього охолодження продукту. Система включає в себе ванни-акумулятори та генератор бінарного льоду скребкового типу. Продукт швидко охолоджують в резервуарах до низької температури та зберігають при необхідному температурному рівні до потрапляння у швидкоморозильні апарати. Морепродукти надходять на заморожування вже охолодженими, щя призводить також до зменшення питомих витрат енергї̈ на обробку риби та зменшення втрат маси продукту від усушки. Розроблено технологічну схему руху морепродуктів від моменту підйому на борт, до моменту завантаження в трюм для зберігання. Розраховано теплові баланси для резервуарів з продуктом, з урахуванням усіх видів витрат. Визначено кількість бінарної сумімі, необхідної для підтримки технологічного режиму. Розраховано та підібрано скребковий генератор бінарного льоду, який задовольняє необхідному навантаженню. Для того, щзоб визначити економічну доцільність використання системи попереднього охолодження бінарним льодом, було проведено техніко-економічний порівняльний аналіз. Навіть не враховуючи значно вищу якість кінцевого продукту, орієнтований термін окупності додаткових вкладень складає близько двох років, за рахунок зниження енергозатрат при заморожуванні.
\end{abstract}

Ключові слова : системи акумуляиії холоду; бінарний лід; холодильний ланцююг; попереднє охолодження.

doi: https://doi.org/ 10.15673/ret.v55i3.1572

(C) The Author(s) 2019. This article is an open access publication

This work is licensed under the Creative Commons Attribution 4.0 International License (CC BY)

http://creativecommons.org/licenses/by/4.0/

\section{1. Вступ}

Поняття «холодильний ланцюг» має на увазі процес забезпечення безперервного впливу холоду на харчові продукти від часу їх виробництва (заготовки) до моменту споживання. Повний «холодильний ланцюг» для рибної промисловості це рух продукту за наступною послідовністю: промислові судна (сейнери, траулери та ін.) $\rightarrow$ приймально-транспортні рефрижераторні судна $\rightarrow$ портові холодильники $\rightarrow$ залізничний або авторефрижераторний транспорт $\rightarrow$ розподільні або виробничі холодильники $\rightarrow$ торгові та побутові холодильники [1].

Один 3 основних принципів роботи «холодильного ланцюга» це те, що температуру продукту, який має найвищу якість на початковому етапі свого життєвого циклу, треба якомога найшвидше знизити до температури зберігання. Далі досить підтримувати технологічні вимоги зберігання, в результаті чого можна знизити втрати якості і маси продукту до мінімуму. 
На великих судах, типу траулерів, які займаються постійним виловом риби в тропічних $\mathrm{i}$ субтропічних районах світових океанів, існує проблема в забезпеченні обробки холодом всього виловленого улову. Потужності холодильної обробки, встановлені на таких судах, дозволяють переробити швидко тільки частину улову, який вже підняли на борт. В цей час, інша частина риби, яка досить швидко починає псуватися, знаходиться при температурах в кращому випадку близьких до температури забортної води, яка в цих водах не нижче $20^{\circ} \mathrm{C}$. В результаті, до кінця циклу переробки, деяка частина улову виявляється в некондиційному стані. При цьому потужностей переробки зіпсованої риби на рибну муку також зазвичай не вистачає. Це призводить до того, що зіпсовану рибу доводиться змивати за борт судна, порушуючи при цьому встановлені правила і закони, що підпадає під штрафні санкції.

\section{2. Технологічна схема обробки продукту}

Метою нашої роботи була розробка та дослідження процесу безперервної холодильної обробки продукту від моменту його вилову до зберігання в низькотемпературних трюмах суд- на. Для дослідження нами було вибрано судно стандартній комплектації супертраулер морозильник типу «Наталя Павличенко». Судно займається видобутком риби типу скумбрії, сардинели і ставриди. Основна частина виловленої риби заморожується в швидкоморозильних апаратах, залишки переробляються на рибну муку.

Загальна місткість низькотемпературних трюмів судна 2000 тонн. Через кожні 30 днів до судна підходить транспортне рефрижераторне судно, на яке вивантажується заморожена риба.

Нами був розроблений технологічний процес циклу холодильної обробки риби, який у вигляді схеми представлений на рисунку 1.

Для досягнення максимальної якості продукції, риба, яка надходить на скороморозильні апарати, повинна бути охолоджена до температури максимально близькою до криоскопичної. При розробці нашої установки було прийнято, що охолодження риби в ваннах буде здійснюватися бінарним льодом.

Бінарний лід, це суміш розчину води та льоду, при тому, що розміри частинок льоду мають початкові лінійні розміри не більш 1-2 мм [3]. У нашому випадку, як розчин води, використається забортна морська вода. Даний холодоносії має високі енергетичні показники теплопередачі і акумуляції холоду [2].

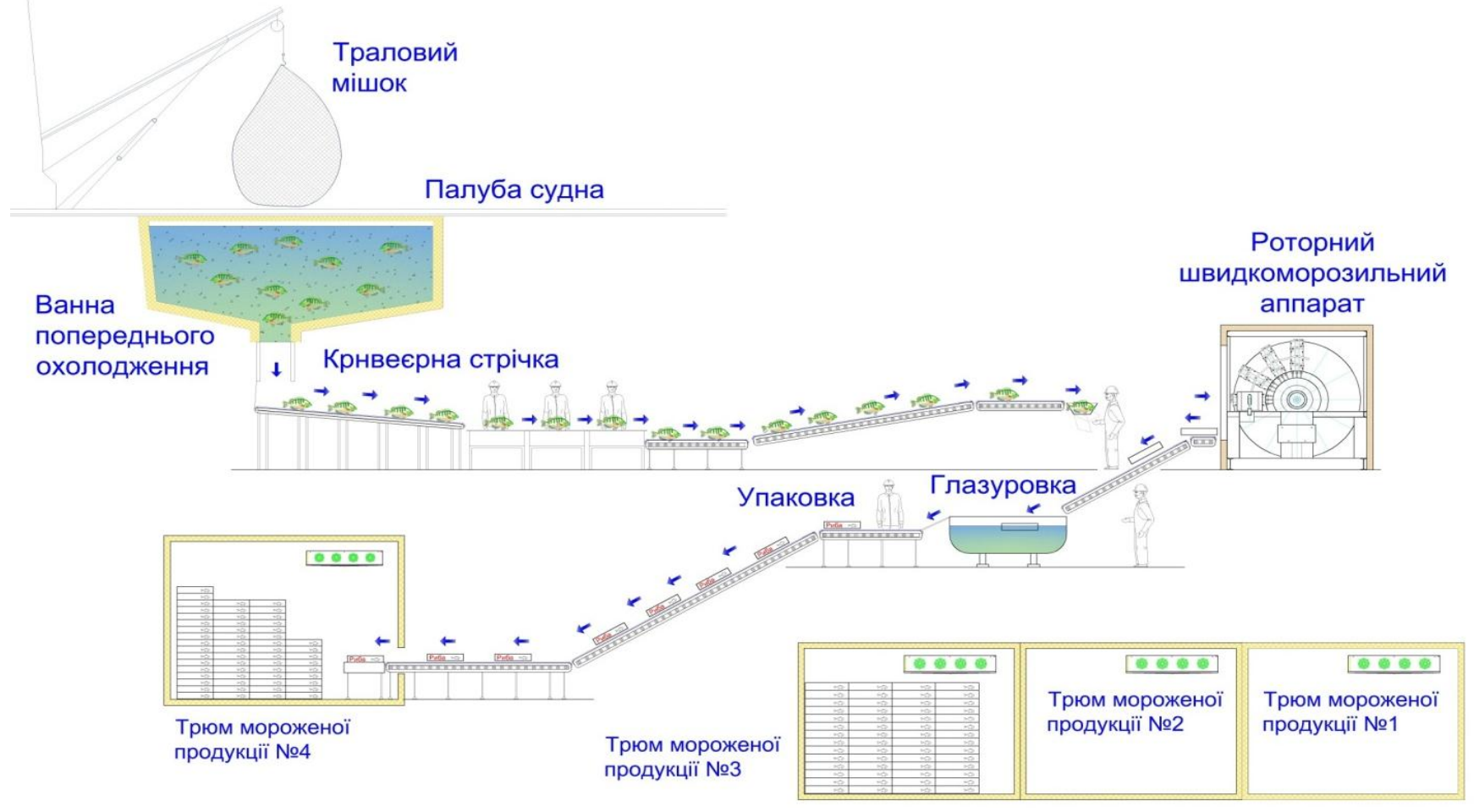

Рисунок 1 - Технологічна схема обробки продукту на судні 


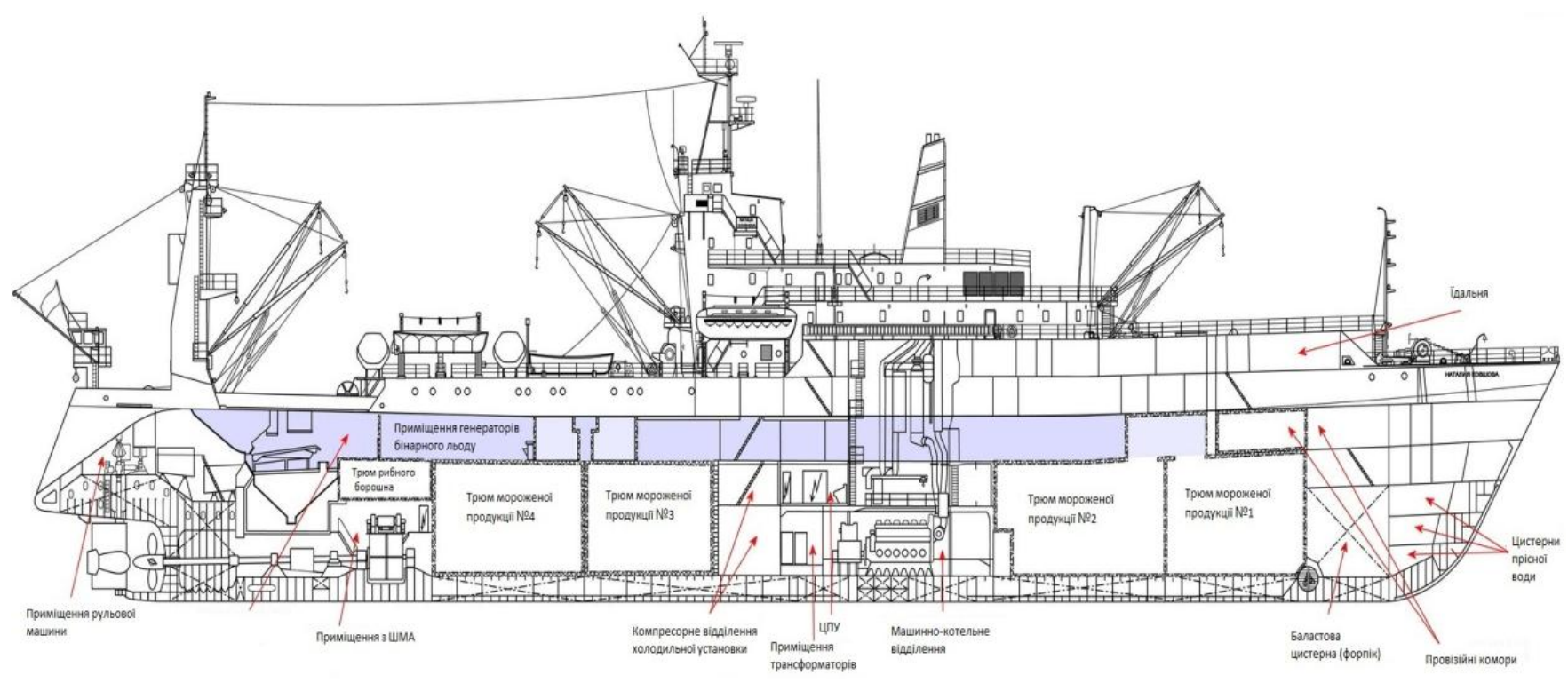

Рисунок 2 - Розташування устаткування на судні

На відміну від охолодження лускатим льодом, ефективність охолодження бінарним льодом (ice slurry), значно вище. Морепродукти в процесі обробки не пошкоджуються, час охолодження продукту зменшується.

Таким чином, відповідно до схеми, риба після вилову, розподіляється по ваннам, де охолоджується бінарним льодом до температури близької до криоскопічної. Охолоджена риба протягом часу переробки зберігається у охолоджуючих ваннах, а потім по конвеєрам надходить до швидкоморозильних апаратів.

У якості швидкоморозильних апаратів на судні будуть встановлені два роторних швидкоморозильних апарата, продуктивністю 25 тонн на добу кожний. Риба заморожується у вигляді брикетів масою по 12 кг, після чого глазурується, упаковується в поліетиленові пакети і укладається в картонні паки по 3 штуки, загальною масою 36 кг.

Далі, паки з замороженої рибою потрапляють 3 конвеєрів в низькотемпературні трюми, в яких риба зберігається при температурі камери мінус $25{ }^{\circ} \mathrm{C}$ до моменту перевантаження на рефрижераторне судно.

\section{3. Техніко-економічне обгрунтування}

У відповідності 3 необхідними витратами холоду на охолодження риби від початкової те- мператури до температури близької до кріоскопічної, а також втратами холоду в навколишне середовище, було визначено необхідну кількість водольодяної суміші. Ванни-резервуари, які підібрано відповідно необхідного обсягу морепродуктів з бінарним льодом, повинні бути обладнані теплоізоляційною сорочкою, що знижує втрати холоду. В процесі зберігання продукту концентрація льоду в водольодяній суміші не повинна знижуватися до нуля, таким чином, це забезпечує постійну температуру морепродуктів, близьку до кріоскопічної. За принципом роботи, ці резервуари $є$ акумуляторами холоду, які обладнано системою підтримки постійного температурного режиму [8].

Енергетично ефективність бінарного льоду може бути оцінена різницею ентальпії холодоносія на протязі процесу охолодження. Падіння ентальпії відбувається зі зміною частки льоду в суміші при постійній температурі суміші:

$$
\mathrm{h}_{\text {б.п }}-\mathrm{h}_{\text {б.к }}=\left(\xi_{\text {л.вх }}-\xi_{\text {л.вых }}\right) \cdot\left(\mathrm{h}_{\text {л }}-\mathrm{h}_{\mathrm{B}}\right), \text { Дж/кг, }
$$

де $\mathrm{h}_{\tilde{0} . п}, \mathrm{~h}_{\tilde{0} . \mathrm{k}}-$ питома ентальпія бінарного льоду на початку та при кінці процесу, Дж/кг.

$\xi_{\text {л.вх }}$ - масова частка льоду в суміші на вході в акумулятор;

$\xi_{\text {л.вых }}-$ кінцева масова частка льоду в сумішi;

$\mathrm{h}_{л}, \mathrm{~h}_{\text {в }}$ - питома ентальпія льоду i води при температурі суміші, Дж/кг. 
Існують кілька різних типів генераторів бінарного льоду, які можуть бути використані в даній холодильній установці [4]. Одними з найбільш надійних і ефективних є генератори скребкового типу [6,7]. 3 урахуванням особливостей роботи був обраний і підібраний по продуктив ності генератор бінарного льоду фірми Sunwell (рис. 3). Цей генератор скребкового типу, являє собою агрегатовану холодильну установку, що забезпечує виробництво, акумуляцію та подачу бінарного льоду з необхідною концентрацією і витратою [5].

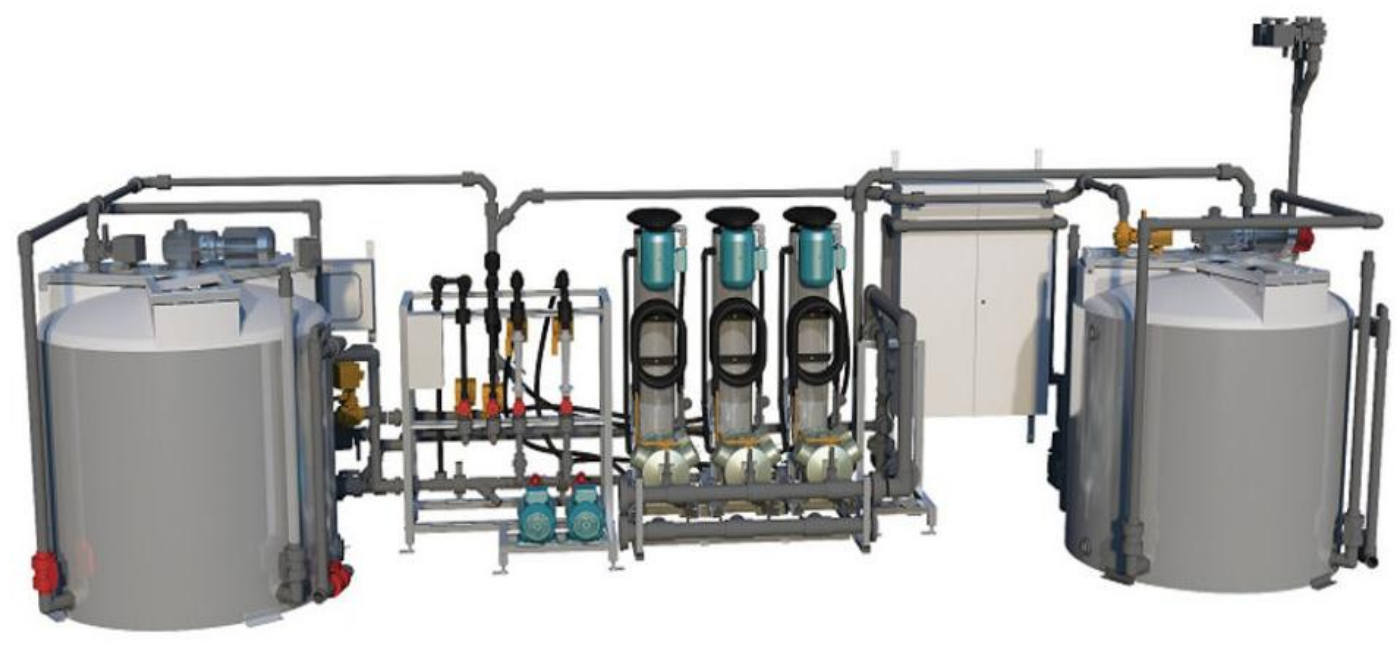

Рисунок 3 - Генератор бінарного льоду скребкового типу SUNWELL

Крім явного ефекту - збереження якості морепродуктів, що надходять на заморожування, попереднє охолодження також дає додаткові переваги. По-перше, це знижені втрати від усушки продукту при заморожуванні, що означає зниження втрат в кінцевій масі продукту. Охолодження продукту до кріоскопічної температури відбувається в льдоводяной суміші, що перешкоджає міграції вологи з поверхні продукту. Таким чином, морепродукти надходять на заморожування 3 температурою продукту значно нижче, ніж в технологічних схемах без попереднього охолодження. Зниження кількості теплоти, яку необхідно відвести від продукту при заморожуванні, призводить до зменшення втрат маси і підвищенню якості кінцевого продукту після заморожування, зберігання і подальшого розморожування.

У нашому випадку заморожування продукту відбувається у роторних швидкоморозильних апаратах у вигляді блоків. Час заморожування визначався за формулою Планка:

$$
\tau=\frac{q_{3} \mathbf{Q}_{\mathrm{II}}}{t_{\mathrm{kp}}-t_{\mathrm{c}}} \delta\left(R \frac{\delta}{\lambda_{3}}+P \frac{1}{\alpha}\right)
$$

де $\mathrm{q}_{3}$ - питома кількість теплоти, яка відводиться від 1 кг риби при заморожуванні від початкової до кінцевої температури, Дж/кг;

$\rho$ - щільність блока риби, кг $/ \mathrm{M}^{3}$;

$\delta$ - товщина блоку, м;

$\mathrm{t}_{\text {кр }}$ - кріоскопічна температура для риби, ${ }^{\circ} \mathrm{C}$;

$\mathrm{t}_{\mathrm{c}}$ - температура кипіння агенту, ${ }^{\circ} \mathrm{C}$;

$\lambda_{3}-$ коефіцієнт теплопровідності замороженої риби;

$\mathrm{R}, \mathrm{P}$ - коефіцієнти форми.

Зниження початкової температури риби, яка потрапляє на заморожування, $320{ }^{\circ} \mathrm{C}$ до $0{ }^{\circ} \mathrm{C}$, за рахунок охолодження бінарним льодом, дає можливість знизити час заморожування 364 хвилин до 48 хвилин. Це пропорційно зменшує витрати маси продукту при заморожуванні в 1.5 рази.

По-друге, попереднє охолодження дає економію енергетичних ресурсів, що витрачаються при заморожуванні, а також підвищує питому продуктивність швидкоморозильних апаратів. Як відомо, холодильні машини швидкоморозильних апаратів працюють при низьких температурах кипіння $\left(-35 \div-40{ }^{\circ} \mathrm{C}\right)$, що призводить до низької енергетичної ефективності. Генератор бінарного льоду даної конструкції, в свою чергу, працює при відносно високих температурах кипіння 
$\left(-15 \div-20{ }^{\circ} \mathrm{C}\right)$. Переміщення значної частини охолодження на більш високий температурний рівень дозволяє значно знизити питомі витрати енергії на одиницю морепродуктів, які заморожуються.

Були проведені варіантні розрахунки швидкоморозильних апаратів з урахуванням зниження початкової температури продукту від температури навколишнього повітря до температури на кілька градусів вище кріоскопічної, згідно існуючим методикам розрахунку подібних апаратів [9]. Визначено питомі енергетичні показники витрати холоду та електроенергії.

Був проведений повний техніко-економічний порівняльний аналіз холодильного ланцюга обробки морепродуктів звичайного та з використанням системи попереднього охолодження бінарним льодом. Визначено орієнтовні капітальні та експлуатаційні витрати, собівартість холоду та терміни окупності. За рахунок переведення частки потрібної холодопродуктивності на більш енергоефективний температурний рівень виробництва, експлуатаційні енергетичні витрати при використанні системи попереднього охолодження знижаються, що дозволяє окупити додаткові капітальні витрати за термін близько двох років.

\section{2. Висновки}

1. Розроблено технологічну схему обробки риби на судні з застосуванням системи попереднього охолодження бінарним льодом. Проведено розрахунки для визначення необхідного обсягу акумуляторів бінарної суміші та продуктивності льодогенератора. Відповідно розрахунковому навантаженню підібрано генератор бінарного льоду з існуючих аналогів з урахуванням особливостей роботи.

2. Проведено варіантні розрахунки продуктивності роторних швидкоморозильних апаратів, в залежності від початкової температури риби, яка надходить на обробку. Визначено, що при максимальному охолодженні риби до температури близької до кріоскопічної, час заморожування знижається 364 хвилин до 48 хвилин, що дає можливість збільшити добову продуктивність апаратів, а також зменшує витрати маси при холодильної обробці в 1.5 рази.
3. Проведено техніко-економічний порівняльний аналіз звичайної технологічної схеми обробки риби з схемою, в якої застосовано систему попереднього охолодження бінарним льодом. Вартість системи попереднього охолодження достатньо висока, але орієнтований термін окупності складає близько двох років, за рахунок зниження енергозатрат.

\section{Література}

1. Хмельнюк М.Г. Холодильні установки та сфери їх використання: підручник / М.Г. Хмельнюк, О.С. Подмазко, І.О. Подмазко // Одеська нац. академія харчових технологій. - Херсон : Грінь Д.С., 2014. - 484 с.

2. Egolfa, P.W. Thermodynamics and heat transfer of ice slurries / P. W. Egolfa, A. Kitanovskia // International Journal of Refrigeration. - January 2005. - P.51-59;

3. Bellas B. Present and future applications of ice slurries / B. Bellas, S. A. Tassou. // International Journal of Refrigeration. - 2005. - №56. - C. 115121.

4. Egolf, P.W. From physical properties of ice slurries to industrial ice slurry applications / P.W. Egolf, M. Kauffeld // International Journal of Refrigeration. - January 2005. - P.4-12;

5. Ice slurry systems [Електронний ресурс] - Peжим доступу до ресурсу: http://sunwell.com/.

6. Martínez, D.S. Analysis of heat transfer phenomena during ice slurry production in scraped surface plate heat exchangers. / Martínez, D.S.; Solano, J.P.; Illán, F.; Viedma, A. //Int. J. Refrig. - 2014 - P.221232.

7. Rayhan, F.A.; Pamitran, A.S. Performance of ice slurry generator with mechanical scraper using R-22 and R-290 / Rayhan, F.A.; Pamitran, A.S. // Int. J. Technol. - 2017 - P.1191-1196.

8. Зимин А.В. Системы аккумуляции холода с использованием бинарного льда / А.В. Зимин // Холодильная техника и технология. -2015 . - №4 (51). - C. 17-20.

9. Бараненко А.В. Примеры и задачи по холодильной технологии пищевых продуктов / А.В. Бараненко, В.Е. Куцакова, Е.И. Борзенко, С.В. Фролов. // 2 изд, испр.и доп. - СПб: ГИОРД, 2012. - 272 c. 


\title{
Investigation of a binary ice pre-cooling system on fishing vessels
}

\author{
A. V. Zimin ${ }^{\bowtie}, M . V$. Slivinska
}

Odessa National Academy of Food Technologies, 112 Kanatna str, Odesa, 65039, Ukraine

$\triangle$ e-mail: onaft.zimin@gmail.com, ORCID ID: https://orcid.org/0000-0001-9053-3262

Cold chain management always been essential in the seafood processing industry. Storing fish at the required temperature level from catching until supplying to the customer can ensure both its freshness and quality. Upkeeping of the cold chain and watchful seafood handling are an essential issue in reducing its spoilage. In seafood business cold chain starts when fish is caught. Concerning quality together with regulatory standpoint fresh fish means storage temperature levels at $0^{\circ} \mathrm{C}$, for frozen product $--18^{\circ} \mathrm{C}$ or even lower if its needed. When the storage temperature for fish vary even $1{ }^{\circ} \mathrm{C}$ higher that cause instabilities in the cold chain and results into fish quality loss. For problem solving it is proposed the Slurry-Ice based pre-cooling system. System include Ice storage tanks and Scraper Type Slurry Generator. Product are chilled quickly in the tanks to low temperature and keep storage at required temperature level up to feeding freezers. Reducing product temperature, which is supplied to freezing facilities, results in reducing energy consumption by system elements and storage product mass loose. Fish into the handling process keep quality and its storage time is improved. Seafood processing system is developed from catching fish until loading into board harvest vessels hold. Heat balances are calculated for tanks loaded with product. Required amount of slurry ice is derived per day of seafood processing. Scraper Type Slurry Generator is calculated for the system. We are picked the best equipment available for our specific purpose. In order to derive specific energy consumption for freezers and seafood loose, all required calculations have been performed taking into account product temperature and with precooling and without. Techno-economic analysis work examines $R D \& D$ areas in terms of costs, benefits, risks, uncertainties, and timeframes to evaluate the energy technologies attributes.

Keywords: Cold Storage Systems; Binary Ice; Cooling Chain; Pre-cooling.

\section{References}

1. Khmelniuk, M.G., Podmazko, O.S., Podmazko, I.O. (2014) Kholodylni ustanovky ta sfery ikh vykorystannia: pidruchnyk. ONAFT, Kherson, Grin D.S., 484 p.

2. Egolf, P.W., Kitanovskia, A. (2005) Thermodynamics and heat transfer of ice slurries. International Journal of Refrigeration, 28(1), 51-59. Doi: https://doi.org/10.1016/j.ijrefrig.2004.07.015

3. Bellas, B., Tassou, S. A. (2005) Present and future applications of ice slurries. International Journal of Refrigeration, 28(1), 115-121. Doi: https://doi.org/10.1016/j.ijrefrig.2004.07.009

4. Egolf, P.W., Kauffeld, M. (2005) From physical properties of ice slurries to industrial ice slurry applications. International Journal of Refrigeration, 28(1), 4-12. Doi: https://doi.org/10.1016/j.ijrefrig. 2004.07.014

5. Ice slurry systems [Electronic source] Available at: http://sunwell.com (date of access 11.04.2019).
6. Martínez, D.S., Solano, J.P., Illán, F., Viedma, A. (2014) Analysis of heat transfer phenomena during ice slurry production in scraped surface plate heat exchangers. Int. J. Refrig., 48, 221-232. Doi: https://doi.org/10.1016/j.ijrefrig.2014.07.020

7. Rayhan, F.A., Pamitran, A.S. (2017) Performance of ice slurry generator with mechanical scraper using R-22 and R-290. Int. J. Technol, 8(7), 1191-1196. Doi: https://doi.org/10.14716/ijtech.v8i7.686

8. Zimin, A.V. (2015) Hold-over systems with binary ice utilization. Refrigeration Engineering and Technology, 51(4), 17-20. DOI: 10.15673/04538307.4/2015.44784

9. Baranenko, A.V., Kutsakova, V.E., Borzenko E.I., Frolov, S.V. (2012) Primery i zadachi po kholodilnoi tekhnologii pishchevykh produktov. SPb: GIORD, 272 p.

Received 10 May 2019 Approved 07 June 2019 Available in Internet 30 June 2019 